CZASOPISMO INŻYNIERII LA¿DOWEJ, ŚRODOWISKA I ARCHITEKTURY JOURNAL OF CIVIL ENGINEERING, ENVIRONMENT AND ARCHITECTURE JCEEA, t. XXXIII, z. 63 (4/16), październik-grudzień 2016, s. 79-86

\author{
Krzysztof CZECH ${ }^{1}$ \\ Wojciech GOSK ${ }^{2}$
}

\title{
WPLYW MASY PODSTAW POMIAROWYCH NA REJESTROWANE DRGANIA POWIERZCHNIOWE GRUNTU
}

\begin{abstract}
Rzetelna ocena wpływu drgań propagowanych w ośrodku gruntowym na projektowane budynki i ich użytkowników powinna bazować na wiarygodnych pomiarach terenowych realizowanych przez doświadczony zespół badawczy przy wykorzystaniu sprzętu pomiarowego o parametrach dostosowanych do poziomu i częstotliwości rejestrowanych drgań. Jak wynika $z$ ostatnich prac badawczych związanych z propagacją drgań powierzchniowych istotny jest również sposób, w jaki czujniki są ,związane” z gruntem (typ podstaw pomiarowych, ilość i długość prętów kotwiących, itp.). Celem niniejszej pracy jest analiza wpływu masy wybranego typu podstaw pomiarowych i montowanych do niej czujników na poziom i wiarygodność rejestrowanych przyspieszeń drgań powierzchniowych ośrodka gruntowego. W badaniach wykorzystywany jest system pomiarowy LAN-XI firmy Brüel\&Kjær z 24-bitowymi modułami typu 3050-B-060 oraz zróżnicowane pod względem czułości i mas czujniki pomiarowe wiodących producentów. Akcelerometry montowano do trójpunktowo zakotwionych $\mathrm{w}$ gruncie pierścieniowych podstaw pomiarowych rozmieszczonych w odległości 5 m i $10 \mathrm{~m}$ od powtarzalnego źródła drgań, jakim była lekka płyta dynamiczna typu ZFG-01. W pracy analizowane są uśrednione wartości szczytowe przyspieszeń drgań z sześciu powtórzeń oraz wartości odpowiadających im odchyleń standardowych. W wyniku przeprowadzonych badań i analiz porównawczych potwierdzono istotność wpływu masy podstaw pomiarowych z zamontowanymi do nich czujnikami na rejestrowane wartości przyspieszeń drgań.
\end{abstract}

Słowa kluczowe: drgania powierzchniowe, przyspieszenia drgań, podstawy pomiarowe, wiarygodność pomiaru

\section{Wprowadzenie}

Jednym z wymogów współczesnej ochrony środowiska jest konieczność podejmowania działań mających na celu minimalizację negatywnych oddziały-

${ }^{1}$ Autor do korespondencji / corresponding author: Krzysztof Czech, Politechnika Białostocka, Katedra Mechaniki Konstrukcji, ul. Wiejska 45E, 15-351 Białystok; tel. +48 604662660; k.czech@pb.edu.pl

${ }^{2}$ Wojciech Gosk, Politechnika Białostocka, Zakład Geotechniki, ul. Wiejska 45E, 15-351 Białystok; tel. +48 501704894; w.gosk@pb.edu.pl 
wań wpływu drgań i hałasu na środowisko [1], [2]. Istotnym ich elementem jest przeprowadzenie wiarygodnych pomiarów terenowych. W przypadku propagacji drgań w gruncie i konieczności oceny ich wpływu na istniejące obiekty budowlane, komfort ich użytkowania, czy też wpływ drgań na urządzenia i maszyny stanowiące wyposażenie budynków, kwestia realizacji wiarygodnych pomiarów nie nastręcza większych problemów. Czujniki pomiarowe w zależności od rodzaju prowadzonej oceny powinny być montowane w miejscach wskazanych przez odpowiednie unormowania $\mathrm{w}$ taki sposób, aby umożliwiały wiarygodną rejestrację drgań elementu konstrukcyjnego, do którego zostały przymocowane (np. fundamenty lub ściany nośne budynków od strony źródła drgań i w poziomie otaczającego terenu [3], fundamenty lub konstrukcje wsporcze maszyn i urządzeń pracujących wewnątrz budynku [3], miejsca odbioru drgań przez ludzi - zazwyczaj w środku rozpiętości stropów [4], itp.).

Problem pojawia się w przypadku konieczności oceny wpływu istniejącego źródła drgań na budynek oraz jego użytkowników, który ma dopiero zostać wzniesiony w danej lokalizacji. Ocena tego typu, poza uwzględnieniem interakcji dynamicznej (do jakiej dochodzi na styku ośrodka gruntowego i budynku), wymaga realizacji wiarygodnych pomiarów propagacji drgań w ośrodku gruntowym w miejscu planowanej inwestycji. Niestety unormowania krajowe jak i zagraniczne nie precyzują, w jaki sposób tego typu pomiary powinny zostać przeprowadzone. Powszechnie stosowaną praktyką jest pomiar drgań za pomocą czujników ustawianych bezpośrednio na gruncie lub za pomocą specjalnie konstruowanych podstaw pomiarowych (kotwionych jak i niekotwionych w gruncie), do których montowane są czujniki. Dowolność w tym zakresie powoduje, że rejestrowane przebiegi czasowe drgań mogą znacznie się od siebie różnić. Wpływ sposobu realizacji pomiarów na poziom uzyskiwanych wartości przyspieszeń drgań powierzchniowych gruntu analizowano między innymi w pracach [5] oraz [6]. Jednakże nie zwrócono w nich uwagi na jeden $z$ aspektów, który może mieć znaczący wpływ na poziom rejestrowanych drgań (niezależnie od przyjętej metodyki prowadzenia pomiarów), a tym samym na ewentualną ocenę wpływu drgań na budynek i jego użytkowników - masę podstawy pomiarowej wraz z zamontowanymi na niej czujnikami.

Celem niniejszej pracy jest analiza wpływu masy wybranego typu podstawy pomiarowej i przykręconych do niej czujników na poziom i wiarygodność rejestrowanych przyspieszeń drgań powierzchniowych ośrodka gruntowego.

\section{Realizacja pomiarów}

\subsection{Lokalizacja pomiarowa}

Pomiary propagacji drgań powierzchniowych przeprowadzono na terenie kopalni odkrywkowej zlokalizowanej w województwie podlaskim w pobliżu miejscowości Bobrowa. Na terenie kopalni stwierdzono występowanie mało 
wilgotnych piasków $\mathrm{P}_{\mathrm{d}} / \mathrm{P}_{\pi}$ (fSa/siSa) w stanie średnio zagęszczonym o dużej jednorodności do głębokości dwóch metrów oraz swobodne zwierciadło wody gruntowej. Nie stwierdzono występowania przewarstwień, ani wtrąceń.

\section{2.Źródło drgań i układ pomiarowy}

Stabilne i powtarzalne źródło drgań impulsowych w trakcie prowadzonych pomiarów stanowiła lekka płyta dynamiczna typu ZFG-01, przy wykorzystaniu której generowano pojedyncze impulsy w wyniku kontrolowanego spadku masy $10 \mathrm{~kg} \mathrm{z}$ wysokości $0,83 \mathrm{~m}$.

Monitoring i rejestrację przebiegów czasowych przyspieszeń drgań generowanych i rozchodzących się w ośrodku gruntowym realizowano za pomocą układu pomiarowego typu LAN-XI firmy Brüel\&Kjær złożonego z dwóch 6-kanałowych, 24-bitowych modułów pomiarowych typu 3050-B-060 (z dynamiką wejść na poziomie $160 \mathrm{~dB}$ ), czujników pomiarowych, okablowania i komputera przenośnego z zainstalowanym dedykowanym oprogramowaniem rejestratora sygnałów i oprogramowaniem do analiz w czasie rzeczywistym (PULSE, REFLEX).

W pomiarach wykorzystano trzy rodzaje piezoelektrycznych czujników przyspieszeń drgań o poniżej zdefiniowanych parametrach i masach (rys. 1):

- czujniki trójosiowe (3D) typu 356B18 firmy PCB o masie $25 \mathrm{~g}$ (zakres pomiarowy $\pm 5 \mathrm{~g}, 0,5 \mathrm{~Hz} \div 3000 \mathrm{~Hz}( \pm 5 \%)$; czułość $1,0 \mathrm{~V} / \mathrm{g})$;

- czujniki jednoosiowe typu 3187D firmy Dytran o masie $122 \mathrm{~g}( \pm 10 \mathrm{~g}$, $0,48 \mathrm{~Hz} \div 1000 \mathrm{~Hz}( \pm 5 \%) ; 0.5 \mathrm{~V} / \mathrm{g})$,

- czujniki jednoosiowe typu 8340 firmy Brüel\&Kjær o masie $775 \mathrm{~g}( \pm 0,5 \mathrm{~g}$, $0,1 \mathrm{~Hz} \div 1500 \mathrm{~Hz}( \pm 10 \%) ; 10 \mathrm{~V} / \mathrm{g})$.

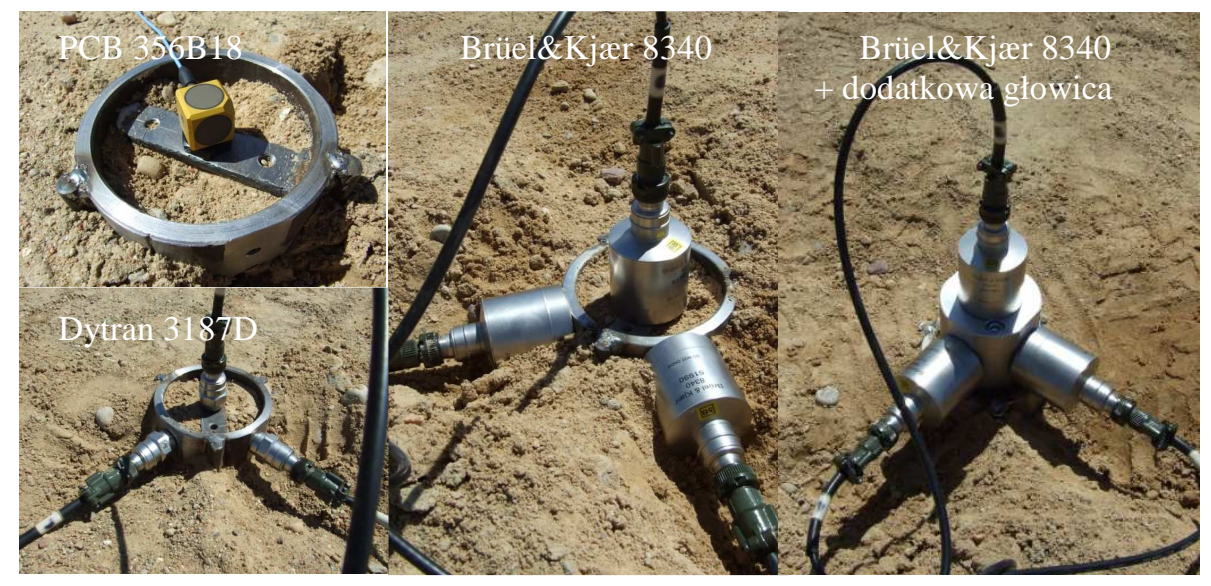

Rys. 1. Podstawy pomiarowe z zamontowanymi czujnikami przyspieszeń

Fig. 1. Measurement bases with mounted accelerometers 
Każdy z wyżej wymienionych czujników charakteryzuje się parametrami właściwymi do wiarygodnej rejestracji przebiegów czasowych przyspieszeń drgań generowanych lekką płytą dynamiczną i propagowanych w bezpośrednim jej sąsiedztwie w ośrodku gruntowym. Czujniki pomiarowe pomimo znacznie zróżnicowanych czułości (od 0,5 do $10 \mathrm{~V} / \mathrm{g}$ ) mają zbliżone zakresy częstotliwości i w przypadku dość intensywnych drgań z dominującymi amplitudami na poziomie kilkuset $\mathrm{mm} / \mathrm{s}^{2}$ i odpowiadającymi im częstotliwościami w zakresie od kilku do kilkuset $\mathrm{Hz}$ nie powinny mieć istotnego wpływu na przebiegi rejestrowanych przyspieszeń drgań.

\subsection{Podstawy i profil pomiarowy}

Przyjęto, że wpływ masy podstawy pomiarowej wraz z układem zamontowanych do niej czujników na poziom rejestrowanych przyspieszeń drgań zostanie przeanalizowany na przykładzie podstaw pomiarowych $\mathrm{w}$ formie stalowego pierścienia $\mathrm{z}$ trzema bolcami $(\mathrm{L}=15 \mathrm{~cm})$ zagłębianymi $\mathrm{w}$ gruncie. Ich przydatność w tego typu badaniach została potwierdzona w trakcie wcześniejszych badań autorów, które opisano między innymi w pracy [5].

Podstawy pomiarowe zagłębiono w ośrodku gruntowym w dwóch punktach pomiarowych (p.p.) oddalonych promieniście od źródła drgań o 5,0 m (1.p.p.) i 10,0 m (2.p.p). Rejestrację przebiegów czasowych przyspieszeń drgań każdorazowo prowadzono $\mathrm{w}$ trzech wzajemnie prostopadłych kierunkach $(x-$ poprzecznym, $y$ - podłużnym oraz $z$ - pionowym). W związku z impulsowym charakterem źródła drgań rejestrację przyspieszeń prowadzono z szybkością 4096 próbek na sekundę. Każdorazowo realizowano po sześć powtórzeń.

Zróżnicowanie mas realizowano poprzez przyklejenie lub przykręcenie do podstaw pierścieniowych poszczególnych typów czujników. Najlżejsze, miniaturowe czujniki 3D montowano do podstaw pomiarowych za pomocą dedykowanego wosku. Pozostałe czujniki przykręcano bezpośrednio do podstaw pierścieniowych lub do dodatkowej głowicy w formie aluminiowego walca, która dodatkowo zwiększała masę podstaw pomiarowych.

W tym miejscu należy zaznaczyć, że podejmowane czynności związane ze zwiększaniem mas podstaw pomiarowych (wynikające ze zmiany typu czujników lub wprowadzenia dodatkowej masy), nie wiązały się z koniecznością ponownego ingerowania w ośrodek gruntowy, gdyż w żaden sposób nie wpływały na zmianę warunków zakotwienia podstaw. Podstawy raz zagłębione w gruncie pozostawały w danym punkcie pomiarowym aż do zakończenia pomiarów.

\section{Wyniki badań}

Zarejestrowane dane analizowano w oprogramowaniu REFLEX. Dla wszystkich zarejestrowanych akcelerogramów wyznaczono wartości szczytowe przyspieszeń drgań propagowanych w ośrodku gruntowym, a następnie dla po- 
szczególnych serii pomiarowych dokonano uśrednienia wartości z sześciu pomiarów. Dodatkowo obliczono odchylenia standardowe, które najlepiej obrazują w jakim stopniu wyniki są rozrzucone wokół wartości średnich. Uzyskane wielkości zestawiono $\mathrm{w}$ formie tabelarycznej (tab. 1 i tab. 2) w funkcji kierunku pomiaru $(x, y, z)$ i odległości od źródła drgań (5 m i 10 m).

Tabela 1. Wartości szczytowe przyspieszeń drgań

Table 1. Peak accelerations of vibration

\begin{tabular}{|c|c|c|c|c|c|c|}
\hline \multirow{2}{*}{$\begin{array}{c}\text { Masa czujników } \\
\text { i podstawy pomiarowej } \\
\text { (liczba kotew / głowica) }\end{array}$} & \multicolumn{3}{|c|}{ Średnia arytmetyczna (odchylenie standardowe), $\mathrm{mm} / \mathrm{s}^{2}$} \\
\cline { 2 - 7 } & \multicolumn{2}{|c|}{$\mathrm{L}=\mathbf{5}$ m (1.p.p.) } & \multicolumn{3}{c|}{$\mathrm{L}=\mathbf{1 0}$ m (2.p.p.) } \\
\cline { 2 - 7 } & $\boldsymbol{x}$ & $\boldsymbol{y}$ & $\boldsymbol{z}$ & $\boldsymbol{x}$ & $\boldsymbol{y}$ & $\boldsymbol{z}$ \\
\hline ok. 1,0 kg & 472 & 725 & 781 & 308 & 323 & 447 \\
$(1 \times$ PCB356B18) & $(133)$ & $(104)$ & $(40)$ & $(119)$ & $(82)$ & $(59)$ \\
\hline ok. 1,3 kg & 339 & 561 & 502 & 148 & 204 & 312 \\
$(3 \times$ DYTRAN 3187D) & $(47)$ & $(41)$ & $(25)$ & $(24)$ & $(20)$ & $(26)$ \\
\hline ok. 3,3 kg & 391 & 513 & 564 & 173 & 315 & 300 \\
$(3 \times$ B\&K 8340) & $(93)$ & $(51)$ & $(29)$ & $(14)$ & $(24)$ & $(9)$ \\
\hline ok. 4,2 kg & 374 & 409 & 629 & 254 & 307 & 309 \\
$($ głowica + 3 $\times$ B\&K 8340) & $(54)$ & $(9)$ & $(36)$ & $(21)$ & $(9)$ & $(3)$ \\
\hline Wartości średnie ze & $\underline{394}$ & $\underline{552}$ & $\underline{619}$ & $\underline{221}$ & $\underline{287}$ & $\underline{342}$ \\
wszystkich pomiarów & $(82)$ & $\underline{(51)}$ & $\underline{(33)}$ & $(45)$ & $(34)$ & $(24)$ \\
\hline
\end{tabular}

\section{Analiza wyników badań}

Porównanie uśrednionych wartości szczytowych przyspieszeń drgań (tab. 1) wskazuje, że zgodnie z oczekiwaniami w kierunku podłużnym (kierunek y) każdorazowo uzyskano znacznie większe wartości niż w kierunku prostopadłym do przyjętego profilu pomiarowego (kierunek $x$ ) - zarówno w pierwszym (1.p.p.; $\mathrm{L}_{1}=5 \mathrm{~m}$ ), jak i drugim punkcie pomiarowym (2.p.p.; $\mathrm{L}_{2}=10 \mathrm{~m}$ ). W większości przypadków maksymalne wartości szczytowe przyspieszeń drgań odnotowano w kierunku pionowym $(z)$.

Analiza porównawcza odchyleń standardowych wyznaczonych dla poszczególnych serii i kierunków pomiarowych wskazuje na największe rozrzuty wartości przyspieszeń drgań w przypadku miniaturowego czujnika 3D firmy PCB o czułości 1V/g (kilkukrotnie większe niż w pozostałych przypadkach). Odchylenia standardowe wyznaczone dla wartości szczytowych przyspieszeń drgań rejestrowanych przy wykorzystaniu czujników typu 3187D firmy Dytran $(0,5 \mathrm{~V} / \mathrm{g})$ oraz typu 8340 firmy B\&K $(10 \mathrm{~V} / \mathrm{g})$ są dużo mniejsze i wykazują znaczne podobieństwo. Wielokrotnie rozrzuty rejestrowanych wartości są nawet mniejsze w przypadku czujnika typu 3187D. Bazując na wartościach odchyleń standardowych prezentowanych $\mathrm{w}$ tab. 1. należałoby stwierdzić, że miniaturowy czujnik wykorzystywany $\mathrm{w}$ przeprowadzonych badaniach pomimo istotnych 
zalet (duża czułość, niewielka masa, łatwość montażu na dowolnej podstawie pomiarowej, itp.) zdecydowanie bardziej nadaje się do analiz modalnych konstrukcji niż pomiarów terenowych propagacji drgań w ośrodku gruntowym. Jego niewielkie rozmiary i masa sprawiają, że jest zbyt podatny na czynniki zewnętrzne - między innymi nawet lekkie podmuchy wiatru.

W kwestii wiarygodności realizowanych pomiarów propagacji drgań powierzchniowych w ośrodku gruntowym poza koniecznością zapewnienia odpowiedniego stopnia zespolenia podstawy pomiarowej z gruntem najistotniejsze jest, aby zastosowana podstawa pomiarowa wraz z układem zamontowanych do niej czujników nie podlegała drganiom rezonansowym.

Jako poziom odniesienia do dalszych analiz przyjęto uśrednione wartości szczytowe przyspieszeń drgań ze wszystkich zrealizowanych pomiarów, a następnie niezależnie dla każdej serii pomiarowej określono wyrażone w procentach różnice pomiędzy wartościami szczytowymi i wartościami uśrednionymi, które najlepiej obrazują łączny wpływ mas czujników i podstaw pomiarowych na rejestrowany poziom przyspieszeń drgań powierzchniowych. Wyniki analiz porównawczych zestawiono w tab. 2 .

Tabela 2. Przyrost lub spadek wartości szczytowych przyspieszeń drgań w stosunku do przyjętego poziomu odniesienia

Table 2. Increase or decrease of the peak accelerations in relation to the accepted reference level

\begin{tabular}{|c|c|c|c|c|c|c|}
\hline \multirow{2}{*}{$\begin{array}{c}\text { Masa czujników } \\
\text { i podstawy pomiarowej }\end{array}$} & \multicolumn{3}{|c|}{ L= 5 m (1.p.p.) } & \multicolumn{2}{c|}{ L = 10 m (2.p.p.) } \\
\cline { 2 - 7 } & $\boldsymbol{x}$ & $\boldsymbol{y}$ & $\boldsymbol{z}$ & $\boldsymbol{x}$ & $\boldsymbol{Y}$ & $\boldsymbol{z}$ \\
\hline $\begin{array}{c}\text { ok. 1,0 kg } \\
(1 \times \text { PCB 356B18) }\end{array}$ & $+20 \%$ & $+31 \%$ & $+26 \%$ & $+39 \%$ & $+12 \%$ & $+31 \%$ \\
\hline $\begin{array}{c}\text { ok. 1,3 kg } \\
(3 \times \text { DYTRAN 3187D) }\end{array}$ & $\underline{-14 \%}$ & $+2 \%$ & $\underline{-19 \%}$ & $\underline{-33 \%}$ & $\underline{-29 \%}$ & $-9 \%$ \\
\hline $\begin{array}{c}\text { ok. 3,3 kg } \\
(3 \times \text { B \&K 8340) }\end{array}$ & $-1 \%$ & $-7 \%$ & $-9 \%$ & $-22 \%$ & $+10 \%$ & $\underline{-12 \%}$ \\
\hline $\begin{array}{c}\text { ok. 4,2 kg } \\
(\text { głowica }+3 \times \text { B\&K 8340) }\end{array}$ & $-5 \%$ & $\underline{-26 \%}$ & $+2 \%$ & $+15 \%$ & $+7 \%$ & $-10 \%$ \\
\hline
\end{tabular}

$\mathrm{Z}$ tab. 2. wynika, iż w przypadku najlżejszej podstawy pomiarowej z zamontowanymi czujnikami 3D firmy PCB (ok. $1 \mathrm{~kg}$ ) w każdym z analizowanych kierunków i punktów pomiarowych uzyskano największe wartości szczytowe przyspieszeń drgań. Biorąc pod uwagę, że stal, z której wykonano podstawy pomiarowe charakteryzuje się bardzo małym tłumieniem materiałowym, można przyjąć (bez szczegółowego analizowania widm częstotliwościowych poszczególnych akcelerogramów), że najbardziej wiarygodne są najniższe z zarejestrowanych wartości szczytowych przyspieszeń drgań. Bazując na tym założeniu należy uznać, że wartości szczytowe przyspieszeń drgań rejestrowane za pomocą podstawy pomiarowej z przyklejonymi miniaturowymi czujnikami 3D są mało wiarygodne (znacznie zawyżone). Wychodząc $\mathrm{z}$ tego samego założenia opty- 
malne wydaje się być rozwiązanie bazujące na podstawie pomiarowej i czujnikach o stosunkowo niewielkiej masie własnej typu 3187D (łączna masa podstawy to ok. $1,3 \mathrm{~kg}$ ), w którym to przypadku aż pięć $\mathrm{z}$ wartości szczytowych charakteryzuje się najniższymi wartościami przyspieszeń drgań. $Z$ powyższego zestawienia wynika również, że sejsmiczne czujniki typu 8340 firmy B\&K pomimo najwyższej dokładności pomiarowej w sposób ewidentny poprzez swoją masę wpływają na wzrost rejestrowanych wartości przyspieszeń drgań (masa podstawy z czujnikami wynosi ok. 3,3 kg). Intensyfikacja drgań w tym przypadku jest szczególnie istotna w kierunkach: $x$ i $z$ w 1.p.p. oraz w kierunku $x$ w 2.p.p. Dalszy wzrost masy podstawy pomiarowej (o ok. $0,9 \mathrm{~kg}$ ) realizowany poprzez wprowadzenie dodatkowej głowicy, do której przykręcano tego samego typu czujniki sejsmiczne (typu 8340) powoduje obniżenie wartości przyspieszeń drgań propagowanych w kierunku $y$ w 1.p.p. Jednakże przy mniejszej intensywności drgań rejestrowanych w 2.p.p. wpływa na ich dalszy wzrost w stosunku do wartości rejestrowanych w płaszczyźnie poziomej (w kierunkach $x$ i $y$ ) przy wykorzystaniu mniej masywnych czujników typu 3187D firmy Dytran. Najbardziej zbieżne wyniki $\mathrm{w}$ trakcie badań uzyskano $\mathrm{w}$ kierunku pionowym $z$ w 2.p.p. Wskazuje to na malejący wpływ masy podstawy pomiarowej z czujnikami na poziom drgań rejestrowanych $w$ tym kierunku przy mniejszych amplitudach przyspieszeń drgań.

Analogiczne badania przeprowadzono dla podstaw pierścieniowych z dwukrotnie dłuższymi kotwami $(\mathrm{L}=30 \mathrm{~cm})$ oraz podstaw pomiarowych $\mathrm{w}$ postaci płyt kołowych trójpunktowo kotwionych z głowicami walcowymi. W każdym z powyższych przypadków wpływ masy na poziom rejestrowanych drgań był znaczący.

\section{Wnioski}

Przeprowadzone pomiary terenowe i analizy porównawcze wskazują, że masa podstaw pomiarowych i zamontowanych do nich czujników w sposób istotny może wpływać na poziom rejestrowanych przyspieszeń drgań powierzchniowych propagowanych w ośrodku gruntowym. Niezbędne jest kontynuowanie prac badawczych w tym kierunku i opracowanie stosownych wytycznych odnośnie nie tylko rodzaju stosowanych w pomiarach głowic podstaw pomiarowych (płyta, krzyżak, pierścień), sposobu ich kotwienia w ośrodku gruntowym (długości i podatności połączeń kotew z głowicą), ale także i optymalnej masy podstaw pomiarowych z zamontowanymi do nich czujnikami. Brak tego typu wytycznych może prowadzić do istotnych rozbieżności w wynikach pomiarów prowadzonych w analogicznych warunkach (rodzaj, stan i uwarstwienie gruntu, jego wilgotność, temperatura powietrza, identyczne źródło drgań, itp.) przez różne zespoły badawcze i w efekcie skutkować błędną interpretacją ewentualnego wpływu rejestrowanych drgań na środowisko. 


\section{Literatura}

[1] Kawecki J., Stypuła K.: Zapewnienie komfortu wibracyjnego ludziom w budynkach narażonych na oddziaływania komunikacyjne. Politechnika Krakowska, Kraków, 2013.

[2] Engel Zb.: Ochrona środowiska przed drganiami i hałasem. Wydawnictwa Naukowe PWN, Warszawa, 2001.

[3] PN-85/B-02170. Ocena szkodliwości drgań przekazywanych przez podłoże na budynki.

[4] PN-88/B-02171. Ocena wpływu drgań na ludzi w budynkach.

[5] Czech K. R., Gosk W.: Wpływ sposobu mocowania akcelerometrów na poziom rejestrowanych drgań powierzchniowych ośrodka gruntowego. Biuletyn WAT, 2014, Vol. 63, nr 3, 65-78.

[6] Maciąg E., Tatara T., Chełmecki J.: Badania drgań gruntu i niskich budynków od wpływu komunikacji miejskiej. Inżynieria i Budownictwo, 2005, nr 3, 135-140.

\section{THE INFLUENCE OF MEASUREMENT BASES WEIGHT ON THE RECORDED SURFACE VIBRATIONS OF THE GROUND}

\section{S u m m a r y}

A reliable assessment of the impact of vibration propagated in the subsoil on the designed buildings and their users should base on reliable field measurements. Measurements should be realized by an experienced research teams using high quality test equipment adapted to the level and frequency of the recorded vibrations. The method of sensors anchoring with the ground (the type of measurement basis, the number and length of anchor rods, etc.) is important according to the latest research connected with the surface vibrations propagation. The aim of this study was to analyze the influence of the weight of selected type of measurement bases and mounted sensors on the reliability of the recorded surface vibrations of the ground. The study used a measurement system LAN-XI Brüel\&Kjær with 24-bit modules type 3050-B-060 and sensors varied in terms of sensitivity and weight. Accelerometers were fixed to the metal rings with three pins bolted into the ground and located at a distance of $5 \mathrm{~m}$ and $10 \mathrm{~m}$ from the repetitive source of vibration - light falling weight deflectometer type ZFG-01. The averaged peak values of vibration acceleration and the corresponding standard deviations were analyzed in the paper. As a result of research and comparative analysis it was found the importance of influence of measurement bases weight with mounted sensors on the recorded values of vibration acceleration.

Keywords: surface vibrations, acceleration, measurement bases, measurement reliability

DOI: $10.7862 / \mathrm{rb} .2016 .250$

Przestano do redakcji: $30.06 .2016 r$.

Przyjęto do druku: 20.12.2016 r. 